
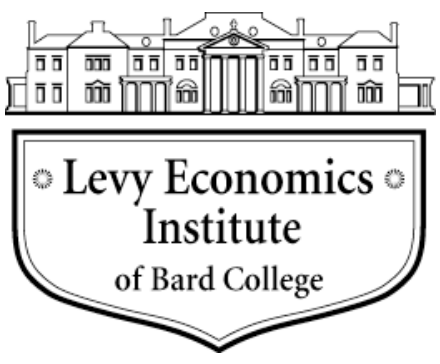

Working Paper No. 794

\title{
Structural Asymmetries at the Roots of the Eurozone Crisis: What's New for Industrial Policy in the EU?
}

by

Alberto Botta*

Mediterranean University of Reggio Calabria

March 2014

*E-mail: abotta@eco.unipv.it

The Levy Economics Institute Working Paper Collection presents research in progress by Levy Institute scholars and conference participants. The purpose of the series is to disseminate ideas to and elicit comments from academics and professionals.

Levy Economics Institute of Bard College, founded in 1986, is a nonprofit, nonpartisan, independently funded research organization devoted to public service. Through scholarship and economic research it generates viable, effective public policy responses to important economic problems that profoundly affect the quality of life in the United States and abroad.

\author{
Levy Economics Institute \\ P.O. Box 5000 \\ Annandale-on-Hudson, NY 12504-5000 \\ http://www.levyinstitute.org
}

Copyright (C) Levy Economics Institute 2014 All rights reserved

ISSN 1547-366X 


\begin{abstract}
In this paper, we analyze and try to measure productive and technological asymmetries between central and peripheral economies in the eurozone. We assess the effects such asymmetries would likely bring about on center-periphery divergence/convergence patterns, and derive some implications as to the design of future industrial policy at the European level. We stress that future European Union (EU) industrial policy should be regionally focused and specifically target structural changes in the periphery as the main way to favor center-periphery convergence and avoid the reappearance of past external imbalances. To this end, a wide battery of industrial policy tools should be considered, ranging from subsidies and fiscal incentives to innovative firms, public financing of $\mathrm{R} \&$ D efforts, sectoral policies, and public procurements for home-produced goods. All in all, future EU industrial policy should be much more interventionist than it currently is, and dispose of much larger funds with respect to the present setting in order to effectively pursue both short-run stabilization and long-run development goals.
\end{abstract}

Keywords: Center-Periphery Structural Symmetries, EU Industrial Policy

JEL Classifications: E12, F15, O25, O52 


\section{INTRODUCTION}

Several economists describe the eurozone crisis in terms of to three main facts. First, before the 2007-2008 financial crash, the process of monetary and financial integration has allowed most peripheral eurozone countries to benefit from considerable capital inflows (Perez-Caldentey and Vernengo, 2012). Accordingly, their economies expanded rapidly, often faster than central economies, giving rise to a sort of center-periphery convergence (see Figure A.1 in the Appendix to the paper). Housing booms took place in Ireland, Spain, and (on to lesser extent) Greece in the first half of the 2000s, and increasing external imbalances emerged much in the same way they did historically in several developing countries after financial liberalization (Stockhammer, 2012) ${ }^{1}$. Second, the worldwide financial dislocation induced by the sub-prime crisis threw all of the eurozone into a deep recession, and forced national governments to come in to bail out close-to-bankruptcy private financial institutions, and provide relief against recession. A prevalently private sector problem has become a public concern (De Grauwe, 2010). The loss of monetary sovereignty by eurozone countries constitutes the third piece of the story, since it has increased the fear of sovereign debt default, and the floor to speculative attacks, as well as capital flights away from externally indebted peripheral countries.

Part of the above problems have a structural nature linked to long-lasting productive asymmetries between peripheral and central economies. According to the findings of this paper, Greece and Portugal are characterized by poorly diversified productive and export structures. Perhaps more relevantly, their economies are mostly concentrated in resource-intensive and labor-intensive low-tech sectors that provide scarce opportunities for introducing product and process innovation. In the case of Ireland, the development of a restricted bunch of high-tech dynamic industries has fed past growth and export performance. However, the Irish productive system is still affected by a lack of diversification, this fact being strikingly evident when capital good sectors are considered ${ }^{2}$. Larger peripheral countries such as Italy and Spain are characterized by more variegated productive and export structures compared to small economies. Yet, in the case of Italy in particular, traditional low-tech and poorly innovative sectors still dominate their productive systems. Given these structural features, finance-led

\footnotetext{
${ }^{1}$ See Figure A.3 in the Appendix to the paper on this point.

2 See also Best (2013) for a critical assessment of FDI-centered industrial policies followed by the Irish government as to their effects on Irish productive system's dynamism and capability to undertake indigenous R\&D and innovation.
} 
growth accelerations have led peripheral countries to run considerable external imbalances, hence mounting external debts, vis-à-vis more developed central economies, by violating rather tight balance-of-payments constraints due to overdependence on imported goods, and difficulties penetrating foreign markets with highly valuable innovative exports (Hein, Truger and van Treeck, 2011) ${ }^{3}$. In this sense, austerity measures (read wage cuts) in the periphery try to address such external disequilibria by fostering price competitiveness of peripheral countries' products through internal devaluation. Since 2007, current account deficits in the peripheral euro countries have been effectively reduced, yet not eliminated or reversed in Greece, Portugal, Italy and Spain. This has happened at the cost of deep recessions. Moreover, there is the concrete risk that austerity measures could fail to restore financial soundness by setting off a vicious spiral between fiscal restrictions, further economic contractions, and deeper fiscal imbalances ${ }^{4}$.

In some previous contributions, we have shown that expansionary fiscal policies implemented by a monetarily sovereign eurozone central government, possibly funded by issuing Eurobonds, would likely represent the definitive way out of the crisis (Botta, 2013a, 2013b). Indeed, expansionary fiscal policies implemented by a federal euro government may favor economic recovery in the periphery, and avoid financial instability from spreading into the entire monetary union. In these contributions, we mainly focused on the short-run anti-cyclical nature of expansionary measures. Here we move to consider how short-run and long-run goals (i.e. reductions in center-periphery structural asymmetries) could be jointly pursued through industrial policies that support productive investment, hence effective demand and economic recovery, and stimulate the long-run growth potential of peripheral countries.

In this paper, we take into account a wide range of policies, from more "traditional" industrial measures influencing industrial and productive dynamics, to public involvement in research and development (R\&D) activities. Nevertheless, they all depend on three main strategic actions. First, a euro-funded industrial policy should considerably increase

\footnotetext{
3 According to data from UNCTAD, Greece, Italy, Spain and Portugal scored remarkable and increasing trade account deficits vis-à-vis Germany since the end of the 90s and until 2008. Before the outbreak of the present crisis, trade deficits versus Germany were as high as 2,13 and 2,22 percent of GDP in the case of Portugal and Spain, respectively (around 1 percent in the case of Italy and Greece). In the case of Ireland, relevant trade account surpluses registered in the second half of the 90 s were driven close to zero just before the burst of the worldwide financial meltdown.

${ }^{4}$ Note that, despite the implementation of fiscal austerity programs, public debt-to-GDP ratios have continuously increased in peripheral countries. In 2012, a partial default has been arranged in Greece.
} 
expenditures devoted to basic research carried out through high-level education institutions. Indeed, according to Dosi et al. (2006), while these efforts are fundamental to expand the scientific knowledge through which applied innovations can be carried out, they create a "business-friendly" environment, and are most welcomed by private corporations. Second, alongside basic research, public-private research centers should strengthen R\&D networks in national innovation systems and focus on applied applications of the above knowledge. Last, but not least, the emergence of innovative firms should be stimulated through public support, let's say subsidies or fiscal incentives. In this regard, sectoral policies should be reconsidered by European institutions. Provided that innovative sectors face highly dynamic demands from international markets, sectoral policies may help the eurozone's periphery to significantly improve its external balance position, and possibly achieve rapid and sustainable growth rates. All in all, we think it is strikingly clear that future eurozone industrial policy should look very different from the current exclusive emphasis on non-distortionary supply-side horizontal policies and market-driven comparative advantages.

This paper is organized as follows. Section 2 provides a picture of structural asymmetries among eurozone countries. We propose the creation of a synthetic Productive Structure Similarity Index (PSSI) through which peripheral countries' productive structures are compared with those prevailing in Germany. Further, we try to assess central-periphery dichotomies as to the degree of (sector) diversification of their productive and export patterns. Section 3 analyses the implications of the above asymmetries in terms of diverging centerperiphery development paths. Here, attention is on the cumulative nature of production development as a technology and innovation process, hence the possible lock-in of peripheral euro countries in a low-growth low-technology-intensive trap. Section 4 discusses how eurolevel R\&D/industrial policy could address such dichotomies, and provide a way out of the crisis by favoring the upgrading of peripheral countries' production patterns. Section 5 concludes. 


\section{CENTER-PERIPHERY STRUCTURAL ASYMMETRIES IN THE EUROZONE}

When finance-led economic booms take place in developing countries, asymmetric productive structures with respect to more developed economies likely give rise to increasing external imbalances. Obviously, capital inflows can easily fill the gap in times of financial euphoria, when financial markets do not care about macroeconomic fundamentals and long-run trends (Krugman, 2009). However, abrupt shocks like the 2007-2008 worldwide financial meltdown very often induce sudden changes in the sentiments of foreign investors, huge capital flights, and painful economic corrections in the host economies.

The most recent economic facts in peripheral eurozone countries broadly follow the above sequence of events, and the tough policy measures they are currently implementing basically aim to deal with the accumulated external debt position. On the one hand, austerity packages may work to reduce imports, by cutting expenditures, depressing economic activity, and (indirectly) bring about a real exchange rate devaluation ${ }^{5}$. On the other hand, since the exchange rate policy is out of the control of national monetary authorities, internal devaluation carried out through sharp wage cuts attempts to spur exports, and possibly, recovery. While these measures desperately try to counteract diverging inflation and unit cost trends between peripheral and central economies ${ }^{6}$, and restore the price competitiveness of peripheral goods, productive structure asymmetries (in the form of the specific types of goods produced and sold) may easily frustrate such efforts. Ultimately, contrary to what is supposed by most international organizations, whereas the export response to internal devaluation may be mild, huge wage cuts may throw the economy into a deep recession and further impinge fiscal solidity ${ }^{7}$.

\footnotetext{
${ }^{5}$ See Gibson and Van Seventer (2000) for an enlightening illustration of the mechanisms through which reductions in public expenditures likely induce a real exchange rate devaluation in a simplified open-economy neoclassical model.

${ }^{6}$ See Dullien and Fritsche (2009), and Bibow (2012) on diverging unit cost dynamics among eurozone countries.

${ }^{7}$ Following the one-sector open economy model proposed by Taylor (1991, chapter 7), we know that: $d u / d w=$ $-(\partial \Delta / \partial w) /(\partial \Delta / \partial u)$, with $\Delta$ being the usual open-economy equilibrium condition, $u=(X / K)$ current capacity utilization, and $w$ the monetary wage rate. Once assumed $(\partial \Delta / \partial u)$ to be negative according to standard stability conditions, the above differential has a negative sign (i.e. wage cuts stimulate economic activity) if $(\partial \Delta / \partial w)$ is negative. A necessary condition for this event to occur reads: $\eta / a-(1-\pi)\left(1-s_{w}\right) X / E>0$ (with $\eta$ being exports elasticity to the real exchange rate, " $a$ " domestic dependence on imported intermediate goods, $\pi$ the profit share, $s_{w}$ saving propensity out of wages, $X$ and $E$ domestic production and exports, respectively). Very likely, some peripheral eurozone countries like Greece and Portugal won't meet the above conditions, due to their relatively low propensity to export, and heavy reliance on domestic demand injections.
} 
What is the extent of the productive asymmetries among eurozone countries, in particular between central and peripheral economies? Simonazzi et al. (2013) have recently provided some evidence on structural differences between Germany and peripheral countries such as Spain, Greece and Portugal. They do so by analyzing cross-country differences in manufactured goods' exports, as synthesized by the Spearman rank correlation coefficient calculated on the revealed comparative advantage (RCA) Balassa index (BI). In this paper, we follow the same logic, but we first focus on differences in the industry composition of the overall domestic manufacturing sector rather than on trade statistics. In more details, we present a Productive Structure Similarity Index (PSSI), which is computed according to the following formula:

$\operatorname{PSSI}_{j t}^{i}=\frac{\left|M_{j t}^{i}-M_{G t}^{i}\right|}{\left(M_{j t}^{i}+M_{G t}^{i}\right)}$ (industry-level PSS Index)

$\operatorname{PSSI}_{j t}=\sum_{i=1}^{i=n}\left[\frac{\left(M_{j t}^{i}+M_{G t}^{i}\right)}{\sum\left(M_{j t}^{i}+M_{G t}^{i}\right)} \operatorname{PSSI}_{j t}^{i}\right] \quad$ (aggregated manufacturing sector PSS Index)

$M_{j t}{ }^{i}$ is the share of sector $i$ on total manufacturing value added in country $j$ at time $t$, and $M_{G t}{ }^{i}$ represents the same figure in the case of Germany ${ }^{8}$. The PSS Index ranges from 0 (identical productive structures) to 1 (absolute divergence in the sectoral composition of the economy). We computed the PSSI for thirteen manufacturing sub-sectors, and for the manufacturing sector as a whole, from 1999 to 2011 . We take into account all the peripheral eurozone countries (the so-called PIIGS). We include in our analysis the Czech Republic and Poland, as well. Actually, these countries do not participate to the monetary union. Yet, according to Simonazzi et al. (2013), their productive structures have been significantly influenced by increasing productive connections with Germany. It might thus be interesting to compare the evolution of their productive structures with those characterizing peripheral euro countries in order to check for the emergence of two different (and diverging) production poles inside Europe. In the case of Spain, Ireland and Greece we also computed a PSS index referred to as the construction sector, in order to emphasize the housing bubble (and the consequences for productive structures)

\footnotetext{
${ }^{8}$ We built the PSS index in the same way as the well-known intra-industry trade Grubell-Lloyd index is. Of course, arguments in the PSS index are industry shares on total manufacturing value added in the economy under consideration and in the benchmark economy (Germany), instead of export and import flows among trading partners.
} 
affecting those countries before the 2007-2008 crisis. Results for the overall manufacturing sector are reported in Table 1 below.

Table 1 Productive Structure Similarity Index (PSSI) Between Selected European Countries and Germany

\begin{tabular}{|c|c|c|c|c|c|c|c|c|c|c|c|c|c|}
\hline Country/Year & 1999 & 2000 & 2001 & 2002 & 2003 & 2004 & 2005 & 2006 & 2007 & 2008 & 2009 & 2010 & 2011 \\
\hline \multicolumn{14}{|l|}{ Austria } \\
\hline PSSI & 0,18 & 0,17 & 0,18 & 0,18 & 0,18 & 0,17 & 0,17 & 0,16 & 0,16 & 0,15 & 0,14 & 0,18 & 0,17 \\
\hline \multicolumn{14}{|l|}{ Czech Republic } \\
\hline PSSI & 0,18 & 0,17 & 0,18 & 0,19 & 0,19 & 0,18 & 0,16 & 0,16 & 0,15 & 0,17 & 0,17 & 0,16 & 0,16 \\
\hline \multicolumn{14}{|l|}{ France } \\
\hline PSSI & 0,14 & 0,14 & 0,17 & 0,18 & 0,18 & 0,18 & 0,17 & 0,18 & 0,19 & 0,18 & 0,17 & 0,20 & 0,20 \\
\hline \multicolumn{14}{|l|}{ Greece } \\
\hline PSSI (M) & 0,40 & 0,40 & 0,38 & 0,37 & 0,39 & 0,38 & 0,38 & 0,37 & 0,39 & 0,39 & 0,41 & 0,44 & 0,45 \\
\hline PSSI (C) & 0,13 & 0,15 & 0,21 & 0,14 & 0,19 & 0,22 & 0,26 & 0,37 & 0,31 & 0,24 & 0,07 & 0,13 & 0,30 \\
\hline \multicolumn{14}{|l|}{ Ireland } \\
\hline PSSI (M) & 0,49 & 0,44 & 0,48 & 0,49 & 0,46 & 0,46 & 0,44 & 0,45 & 0,46 & 0,47 & 0,48 & 0,52 & 0,53 \\
\hline PSSI (C) & 0,10 & 0,16 & 0,22 & 0,22 & 0,27 & 0,36 & 0,43 & 0,46 & 0,40 & 0,26 & 0,21 & 0,41 & 0,46 \\
\hline \multicolumn{14}{|l|}{ Italy } \\
\hline PSSI & 0,19 & 0,19 & 0,20 & 0,21 & 0,22 & 0,21 & 0,21 & 0,21 & 0,22 & 0,22 & 0,19 & 0,22 & 0,22 \\
\hline \multicolumn{14}{|l|}{ Poland } \\
\hline PSSI & 0,29 & 0,29 & 0,30 & 0,29 & 0,28 & 0,28 & 0,28 & 0,26 & 0,29 & 0,29 & 0,24 & 0,29 & - \\
\hline \multicolumn{14}{|l|}{ Portugal } \\
\hline PSSI & 0,31 & 0,30 & 0,31 & 0,33 & 0,34 & 0,34 & 0,35 & 0,35 & 0,35 & 0,35 & 0,33 & 0,35 & - \\
\hline \multicolumn{14}{|l|}{ Spain } \\
\hline PSSI (M) & - & 0,20 & 0,20 & 0,21 & 0,22 & 0,23 & 0,24 & 0,24 & 0,25 & 0,25 & 0,22 & 0,24 & 0,24 \\
\hline PSSI (C) & - & 0,32 & 0,38 & 0,42 & 0,46 & 0,50 & 0,54 & 0,55 & 0,54 & 0,53 & 0,50 & 0,42 & 0,37 \\
\hline
\end{tabular}

Source: Author's calculation on the base of data from Eurostat.

Note: Letters "M" and "C" in parentheses stand for "manufacturing sector" and "construction sector" respectively.

Results reported in Table 1 show that small peripheral eurozone countries such as Greece, Portugal and Ireland present largely different productive structures with respect to those prevailing in Germany. Further, productive asymmetries versus Germany seem to have widened and increased in the aftermath of the most recent financial meltdown and all along the ongoing eurozone crisis. 
More disaggregated data ${ }^{9}$ tell us that most of these asymmetries come from the relative (and increasing) state of backwardness among the above peripheral countries in the production of capital goods, which, on the contrary, stands out as the core of German productive specialization. This evidence may be a sign that productive development is not fully completed in the peripheral economies mentioned before, since the emergence of a considerable capital good sector has been traditionally seen as the most advanced stage in the development process of an economy (Akamatzu, 1962; Ricottilli, 1993; Kojima, 2000). Further, provided that a productive structure featuring a relatively developed capital good sector is an important factor conducive to innovation and growth (Ricottilli, 1993), perverse structural changes linked to the ongoing crisis may have a long-lasting negative impact on the growth potential of small peripheral economies.

Productive asymmetries with respect to Germany are much less evident in the case of larger economies such as Italy and Spain. However, our results tell us that center-(big)peripheral countries' asymmetries are slightly increasing across time, this evidence being different from the conclusions reached by Simonazzi et al. (2013) in the case of Italy. In 2010 and 2011, in particular, the persistent recession affecting peripheral economies seems to have impeded the recovery of the investment goods sector, while Germany has recorded a significant upturn in its most typical industries ${ }^{10}$. Once again, should demand side-supply side interactions in the capital good sector be relevant sources of technological spill-over for the whole economic system, such a temporary shock may impinge long-run economic performances also in the case of larger peripheral countries.

As expected, Austria and the Czech Republic show a productive structure closely similar to that of Germany. In the case of the Czech Republic, according to Simonazzi, et al. (2013), this may be the result of the reorganization of German industries through partial delocalization in Eastern European countries. In the same vein, Poland presents a productive structure more similar to the German one than Portugal and Greece do, even though in 2008 the level of

\footnotetext{
${ }^{9}$ More disaggregated data are available from the authors on request.

${ }^{10}$ According to data from Eurostat, in 2012 gross fixed capital formation (read investment demand) in Germany was higher than its 2005 pre-crisis level. By contrast, in Greece and Ireland investment demand was broadly half than that recorded in 2005. From 2005 to 2012, it has decreased by one-third in Portugal. In the case of Italy and Spain, drops in investment demand amount to 20 and 28 percentage points, respectively.
} 
economic development in Poland (as captured by GDP per-capita) was less than one-half of the Greek one, and barely 60 percent of Portuguese GDP per-capita ${ }^{11}$.

Finally, note the astonishing housing-boom-led expansion of the construction sector in Greece, Ireland and Spain with respect to Germany. Different productive structures often go hand-in-hand with differences in the product composition of exports. In Table 2, we compute the above similarity index by now taking into account the sectoral composition of country exports. Sector definition follows the "technological classification" provided by UNCTAD, according to which export flows are subdivided in four different groups on the basis of their input and technological intensity: resource-based and labor-intensive sectors; low-skill and lowtechnology-intensive sectors; medium-skill and technology-intensive productions; high-skill and technology-intensive industries. Arguments in the now-redefined Export Structure Similarity Index (ESSI) are sectors' export shares on total country exports.

Despite the fact that high levels of aggregation naturally tend to hide structural differences, center-periphery asymmetries appear clearly in the case of Greece, Portugal, and Ireland. By contrast, export structure differences are much lower or rapidly decreasing in the case of Austria, the Czech Republic and Poland. Once again, high or quickly increasing export similarity between Germany, the Czech Republic and Poland is likely due to German companies' outsourcing in the above-East-European countries, and of the ensuing increase in intra-industry trade.

Table 2 Export Structure Similarity Index (ESSI) Between Selected European Countries and Germany

\begin{tabular}{|l|cccccccccccccc|}
\hline Country/Year & $\mathbf{1 9 9 9}$ & $\mathbf{2 0 0 0}$ & $\mathbf{2 0 0 1}$ & $\mathbf{2 0 0 2}$ & $\mathbf{2 0 0 3}$ & $\mathbf{2 0 0 4}$ & $\mathbf{2 0 0 5}$ & $\mathbf{2 0 0 6}$ & $\mathbf{2 0 0 7}$ & $\mathbf{2 0 0 8}$ & $\mathbf{2 0 0 9}$ & $\mathbf{2 0 1 0}$ & $\mathbf{2 0 1 1}$ & $\mathbf{2 0 1 2}$ \\
\hline Austria & 0,19 & 0,18 & 0,19 & 0,18 & 0,19 & 0,16 & 0,16 & 0,15 & 0,15 & 0,16 & 0,16 & 0,16 & 0,16 & 0,17 \\
Czech Republic & 0,18 & 0,17 & 0,17 & 0,14 & 0,16 & 0,15 & 0,15 & 0,16 & 0,15 & 0,16 & 0,17 & 0,16 & 0,16 & 0,17 \\
France & 0,09 & 0,10 & 0,10 & 0,10 & 0,11 & 0,10 & 0,11 & 0,11 & 0,11 & 0,12 & 0,13 & 0,15 & 0,16 & 0,17 \\
Greece & 0,43 & 0,40 & 0,39 & 0,36 & 0,37 & 0,34 & 0,35 & 0,31 & 0,29 & 0,31 & 0,30 & 0,31 & 0,32 & 0,33 \\
Ireland & 0,65 & 0,65 & 0,65 & 0,67 & 0,67 & 0,67 & 0,67 & 0,66 & 0,66 & 0,66 & 0,64 & 0,65 & 0,66 & 0,65 \\
Italy & 0,23 & 0,24 & 0,24 & 0,23 & 0,22 & 0,22 & 0,21 & 0,21 & 0,20 & 0,19 & 0,19 & 0,19 & 0,19 & 0,21 \\
Poland & 0,37 & 0,31 & 0,33 & 0,31 & 0,29 & 0,26 & 0,23 & 0,21 & 0,20 & 0,19 & 0,18 & 0,18 & 0,20 & 0,20 \\
Portugal & 0,38 & 0,36 & 0,37 & 0,36 & 0,35 & 0,34 & 0,32 & 0,30 & 0,31 & 0,30 & 0,31 & 0,30 & 0,30 & 0,30 \\
Spain & 0,09 & 0,10 & 0,10 & 0,10 & 0,09 & 0,10 & 0,10 & 0,11 & 0,09 & 0,10 & 0,10 & 0,10 & 0,11 & 0,11 \\
\hline
\end{tabular}

Source: Author's calculations on data from UNCTAD

\footnotetext{
${ }^{11}$ According to traditional trade theory, trade and productive structures might be expected to become more similar the closer is the development level of the economies under observation. The above results may thus be considered as partially surprising.
} 
The high level of aggregation tends to downsize the value of the ESS index, and therefore of perceived export structure differences with respect to Germany, in the case of large peripheral economies such as Italy and, above all, Spain. Asymmetries, however, partially reemerge if we move on our analysis and consider RCA Balassa indexes associated to the above defined sectors. Data are reported in Table 3.

Consistent with the structural features summarized in Table 1, Germany shows a persistent comparative advantage in medium-tech manufacturing sectors including most capital good industries. From 1999 to 2012, German exports seem to concentrate even further in the medium/high-tech segment of manufacturing goods, while a process of increasing despecialization is taking place in labor and resource-intensive or low-tech sectors. Quite interestingly, the same processes can be detected in countries such as Poland and the Czech Republic. 
Table 3 Revealed comparative advantages in manufacturing sub-groups in selected European Countries.

\begin{tabular}{|c|c|c|c|c|c|c|c|c|c|}
\hline Country/Year & 99 & 05 & 06 & 07 & 08 & 09 & 10 & 11 & 12 \\
\hline \multicolumn{10}{|l|}{ Austria } \\
\hline Labor-intensive and resource-intensive & 1,04 & 0,94 & 0,91 & 0,94 & 0,93 & 0,90 & 0,87 & 0,87 & 0,95 \\
\hline Low-skill and technology-intensive & 1,66 & 1,51 & 1,45 & 1,48 & 1,49 & 1,67 & 1,61 & 1,62 & 1,64 \\
\hline Medium-skill and technology-intensive & 1,07 & 1,17 & 1,17 & 1,16 & 1,17 & 1,17 & 1,16 & 1,15 & 1,11 \\
\hline High-skill and technology-intensive & 0,56 & 0,59 & 0,62 & 0,63 & 0,61 & 0,66 & 0,68 & 0,67 & 0,68 \\
\hline \multicolumn{10}{|l|}{ Czech Republic } \\
\hline Labor-intensive and resource-intensive & 1,06 & 0,85 & 0,80 & 0,79 & 0,76 & 0,72 & 0,69 & 0,69 & 0,68 \\
\hline Low-skill and technology-intensive & 1,78 & 1,51 & 1,41 & 1,35 & 1,32 & 1,35 & 1,29 & 1,33 & 1,35 \\
\hline Medium-skill and technology-intensive & 1,13 & 1,36 & 1,39 & 1,40 & 1,43 & 1,55 & 1,54 & 1,52 & 1,49 \\
\hline High-skill and technology-intensive & 0,50 & 0,43 & 0,42 & 0,42 & 0,42 & 0,42 & 0,42 & 0,41 & 0,42 \\
\hline \multicolumn{10}{|l|}{ France } \\
\hline Labor-intensive and resource-intensive & 0,70 & 0,65 & 0,65 & 0,67 & 0,66 & 0,63 & 0,61 & 0,64 & 0,67 \\
\hline Low-skill and technology-intensive & 1,06 & 0,91 & 0,90 & 0,92 & 0,86 & 0,89 & 0,85 & 0,81 & 0,82 \\
\hline Medium-skill and technology-intensive & 1,01 & 1,04 & 1,01 & 1,00 & 0,99 & 0,98 & 0,94 & 0,94 & 0,90 \\
\hline High-skill and technology-intensive & 1,30 & 1,31 & 1,34 & 1,33 & 1,35 & 1,34 & 1,42 & 1,42 & 1,42 \\
\hline \multicolumn{10}{|l|}{ Germany } \\
\hline Labor-intensive and resource-intensive & 0,57 & 0,53 & 0,53 & 0,54 & 0,55 & 0,54 & 0,53 & 0,54 & 0,51 \\
\hline Low-skill and technology-intensive & 1,01 & 0,92 & 0,91 & 0,90 & 0,86 & 0,93 & 0,90 & 0,86 & 0,88 \\
\hline Medium-skill and technology-intensive & 1,23 & 1,32 & 1,29 & 1,29 & 1,31 & 1,33 & 1,35 & 1,35 & 1,32 \\
\hline High-skill and technology-intensive & 1,09 & 1,01 & 1,03 & 1,02 & 1,02 & 1,01 & 0,99 & 0,97 & 1,01 \\
\hline \multicolumn{10}{|l|}{ Greece } \\
\hline Labor-intensive and resource-intensive & 2,57 & 1,80 & 1,70 & 1,62 & 1,56 & 1,46 & 1,46 & 1,35 & 1,53 \\
\hline Low-skill and technology-intensive & 1,18 & 1,43 & 1,34 & 1,34 & 1,56 & 1,54 & 1,42 & 1,85 & 1,69 \\
\hline Medium-skill and technology-intensive & 0,33 & 0,42 & 0,49 & 0,55 & 0,49 & 0,47 & 0,49 & 0,50 & 0,45 \\
\hline High-skill and technology-intensive & 0,82 & 1,22 & 1,21 & 1,20 & 1,18 & 1,24 & 1,26 & 1,19 & 1,22 \\
\hline \multicolumn{10}{|l|}{ Ireland } \\
\hline Labor-intensive and resource-intensive & 0,23 & 0,14 & 0,14 & 0,14 & 0,12 & 0,08 & 0,11 & 0,10 & 0,11 \\
\hline Low-skill and technology-intensive & 0,19 & 0,10 & 0,11 & 0,12 & 0,10 & 0,08 & 0,09 & 0,10 & 0,10 \\
\hline Medium-skill and technology-intensive & 0,27 & 0,16 & 0,18 & 0,18 & 0,17 & 0,14 & 0,14 & 0,15 & 0,15 \\
\hline High-skill and technology-intensive & 2,92 & 3,19 & 3,14 & 3,18 & 3,13 & 2,91 & 2,95 & 2,98 & 2,97 \\
\hline
\end{tabular}


Table 3 Revealed comparative advantages in manufacturing sub-groups in selected European Countries (Continued).

\begin{tabular}{|c|c|c|c|c|c|c|c|c|c|}
\hline \multicolumn{10}{|l|}{ Italy } \\
\hline Labor-intensive and resource-intensive & 1,49 & 1,40 & 1,39 & 1,36 & 1,35 & 1,29 & 1,31 & 1,32 & 1,39 \\
\hline Low-skill and technology-intensive & 1,21 & 1,27 & 1,27 & 1,31 & 1,25 & 1,40 & 1,32 & 1,30 & 1,30 \\
\hline Medium-skill and technology-intensive & 0,92 & 0,99 & 1,01 & 1,03 & 1,07 & 1,11 & 1,07 & 1,06 & 1,01 \\
\hline High-skill and technology-intensive & 0,65 & 0,69 & 0,67 & 0,65 & 0,63 & 0,64 & 0,68 & 0,68 & 0,70 \\
\hline \multicolumn{10}{|l|}{ Poland } \\
\hline Labor-intensive and resource-intensive & 1,84 & 1,34 & 1,27 & 1,27 & 1,22 & 1,21 & 1,25 & 1,24 & 1,26 \\
\hline Low-skill and technology-intensive & 2,22 & 1,70 & 1,56 & 1,56 & 1,48 & 1,56 & 1,42 & 1,55 & 1,59 \\
\hline Medium-skill and technology-intensive & 0,73 & 1,11 & 1,15 & 1,15 & 1,19 & 1,29 & 1,23 & 1,17 & 1,12 \\
\hline High-skill and technology-intensive & 0,42 & 0,43 & 0,45 & 0,45 & 0,48 & 0,46 & 0,52 & 0,53 & 0,57 \\
\hline \multicolumn{10}{|l|}{ Portugal } \\
\hline Labor-intensive and resource-intensive & 2,42 & 2,22 & 2,17 & 2,25 & 2,21 & 2,18 & 2,18 & 2,19 & 2,12 \\
\hline Low-skill and technology-intensive & 0,67 & 0,88 & 0,95 & 0,98 & 0,95 & 1,04 & 0,97 & 0,95 & 1,10 \\
\hline Medium-skill and technology-intensive & 0,83 & 0,89 & 0,91 & 0,87 & 0,91 & 0,95 & 0,93 & 0,92 & 0,92 \\
\hline High-skill and technology-intensive & 0,36 & 0,48 & 0,48 & 0,51 & 0,51 & 0,46 & 0,52 & 0,54 & 0,54 \\
\hline \multicolumn{10}{|l|}{ Spain } \\
\hline Labor-intensive and resource-intensive & 0,92 & 0,88 & 0,91 & 0,92 & 0,96 & 0,95 & 0,94 & 0,94 & 0,99 \\
\hline Low-skill and technology-intensive & 1,22 & 1,26 & 1,26 & 1,15 & 1,11 & 1,20 & 1,21 & 1,20 & 1,19 \\
\hline Medium-skill and technology-intensive & 1,23 & 1,20 & 1,20 & 1,21 & 1,21 & 1,26 & 1,19 & 1,21 & 1,14 \\
\hline High-skill and technology-intensive & 0,69 & 0,80 & 0,78 & 0,81 & 0,80 & 0,79 & 0,86 & 0,82 & 0,87 \\
\hline
\end{tabular}

Source: Author's calculations on data from UNCTAD

Small peripheral countries such as Greece, Ireland, and Portugal are characterized by a radically different picture. Their export de-specialization in the medium-tech capital good sector is evident and striking in the case of Ireland and Greece. In Greece and Portugal, comparative advantages are still significantly localized in labor and resource intensive and low-tech sectors. In Greece and Ireland, finally, an RCA Balassa index higher than 1 is recorded in the case of high-tech industries. This perhaps surprising result largely depends on the type of manufacturing productions included in such a group. According to UNCTAD classification, most chemical industries are classified as high-tech production. It is in these sectors that Greece and Ireland 
score an increasing export specialization ${ }^{12}$. Germany, on the contrary, is acquiring an increasing specialization in the production of high-tech transport equipment and scientific instruments (sector codes 791 and 87 in the SITC rev. 3 classification). Center-periphery differences that may appear somehow softened at an aggregate level of analysis thus clearly re-emerge when a more disaggregated perspective is adopted.

Italy and Spain are somehow midway on a hypothetical technology ladder from the eurozone periphery to Germany. In the case of Italy, in particular, it is evident that persisting export specialization in labor-intensive and low-tech sectors. Italy also maintain a relatively weak specialization in the mechanical industry (a traditional pillar of Italian exports), whilst (revealed) comparative disadvantages are deep in the high-tech sector.

\subsection{Specialization Versus Diversification in the Eurozone}

Some economists might reply to this analysis by arguing that productive and export differences among countries might not necessarily imply negative consequences on the long-run growth potential of an economy. According to them, trade and monetary integration might actually accelerate economic growth thanks to dynamic economies of scale originating from production and trade specialization (Rivera-Batiz and Romer, 1991; Bachus et al., 1992; Lee, 1995; Lane, 1996). While this argument is generally referred to integration among similar developed countries (Rivera-Batiz and Romer, 1991), two possible answers could be levied against such an objection. First, a traditional response would stress that growth performance depends on the specific sector you specialize in. Growth potential in the periphery may thus worsen (at least with respect to the center) should it perversely specialize in passive sectors experiencing poor technological improvements. Second, according to some recent evidence, economic growth and a relevant part of the development process are significantly characterized by a process of productive ad export diversification, instead of concentration and specialization (Imbs and Wacziarg, 2003; Klinger and Lederman, 2004; Rodrik, 2007). It is the enlargement of the

\footnotetext{
${ }^{12}$ Greece specialization is relevant in the production of fertilizers, perfumes, and plastic goods (sector codes 55, 56 and 57 in the SITC rev.3 classification). In the case of Ireland, specialization is strongly concentrated in the production of perfumes and pharmaceutics goods (sector codes 541, 542 and 551 in the SITC rev. 3 classification at three-digit disaggregation level).
} 
production (export) space of a given economy that allows for growth acceleration and catching up with more advanced countries (Herzer and Novak-Lehmann, 2006; Rodrik, 2007) ${ }^{13}$.

In light of this evidence, here we re-elaborate the analysis carried out in the previous section in order to stress differences between central and peripheral countries as to the diversification of their productive and export bases. Indeed, when we emphasize the need for a process of structural convergence between central and peripheral economies, we do not mean that all them should adopt exactly the same productive structure and export the same types of goods. Yet, we stress that peripheral eurozone countries, in particular some small peripheral economies, should undertake a significant process of innovation-led diversification of their production sectors towards high-tech dynamic sectors in order to partially close the structural gap with respect to more advanced central economies.

There is an intrinsic contradiction between revealed comparative advantages, as measured by Balassa index, and the degree of diversification in an economy's production and export base. The more heterogeneous the range of goods you produce and export on international markets, the lower will be the sectoral Balassa indexes ${ }^{14}$. In order to deal with these technical aspects, in Table 4 we present a series of indicators which, taken together, may perhaps provide a comprehensive perspective on the structural features of selected European countries. Data reported in Table 4 rely on a detailed three-digit decomposition of European countries' exports. In column one we compute the number of manufacturing sectors showing values of Balassa index higher than 0,9 (i.e. those sectors that present or are close to presenting an apparent comparative advantage ${ }^{15}$. Column two reports the median value of the sectoral Balassa indexes. We put emphasis on median Balassa index instead of average one because the former is more robust than the latter. In addition, average values of sectoral Balassa indexes are

\footnotetext{
${ }^{13}$ The specialization/diversification divide may be at least partially reconcile if you think that specialization in the industrial sector away from natural-resource based industries (i.e. a main feature of the development process) generally entails the expansion of the range of home-made manufactured goods. In a way, product diversification may lie behind specialization in manufacturing or traded-good sectors which characterizes fast-growing economies in two-sector models by Krugman (1981) and Matsuyma (1992) among others.

${ }^{14}$ Indeed, this is why average Balassa indexes are generally higher in relatively backward countries with export structures concentrated in a restrict bunch of sectors than in more diversified advanced economies.

${ }^{15}$ Statistics reported in column 1 in Table 3 are computed according to a Balassa index threshold level lower than 1 (i.e. the traditional boundary between revealed comparative advantage and disadvantage), and equal to 0,9 . We do so in light of the above consideration on the inverse relationship connecting revealed comparative advantages and the diversification of an economy export structure. The lower-than-usual threshold we adopt allows us to take into account in our statistics also those industries that register Balassa indexes slightly lower than 1 but that might wrongly be considered as uncompetitive. Their apparent lack of competitiveness may actually derive from a widening of the home economy export base rather than from country's exclusion from international markets.
} 
influenced by in-built asymmetries characterizing the computation of such an indicator: average sectoral Balassa index, taken alone, might provide a distorted image of a country's external competitiveness. ${ }^{16}$ Finally, in the third column of Table 4, we report the inverse of sectoral Balassa indexes' variance. We label such an indicator as the concentration index, since it might provide information about the degree of homogeneity of a country's export structure. Values in parentheses in column three are average values of the sectoral Balassa indexes. Figure 1 graphically reproduces data reported in Table 4. In Figure 1, bubbles' dimensions stand for the abovementioned concentration index. The larger (the lower) the bubble, the higher the sector's comparative advantage concentration (dispersion) around its mean value.

According to Table 4, in Germany, 106 sectors out of 166 manufacturing industries were included in the Standard International Trade Classification (SITC) rev.3, with three-digit classification score Balassa indexes higher than 0,9. This figure is the highest registered amongst the European countries under observation, and far higher than the same statistics recorded in most peripheral countries with the partial exception of Italy. Consistent with the above results, the median Balassa index in Germany is rather high and equal to 1,01. It is much higher than those characterizing peripheral countries (with, again, the exception of Italy). In the case of Portugal, Greece and, in particular, Ireland, median Balassa indexes are considerably lower than 1 . This means that these countries feature highly concentrated export structures: the vast majority of manufacturing sectors show revealed disadvantages, whilst comparative advantages emerge only in a few of them. Such a perspective is corroborated by both the considerable gap that divides median from average Balassa indexes in the above economies (the latter being considerably higher than the former), and by the high dispersion of sectoral comparative advantages (indexes) around corresponding mean values (see small bubbles associated to small peripheral economies in Figure 1). The median and average Balassa indexes are almost equal in Germany. Further, from Figure 1 it becomes astonishingly clear that the deep level of concentration of German manufacturing sectors' Balassa indexes are around the corresponding mean value (dashed vertical line in Figure 1). Needless to say, this is a sign that, on top of increasing price competitiveness, Germany's enthusiastic export performance

\footnotetext{
${ }^{16}$ By construction, Balassa index rages between zero and, potentially, infinite. Accordingly, arithmetic average of sectoral Balassa indexes will naturally increase in case of highly concentrated productive structures. Median values of the above index, on the contrary, better reflect the degree of sectoral polarization of a country productive and export vector.
} 
significantly depends on structural causes, i.e. the diversification of Germany's productive structure and the capability to export a wide range of goods.

Table 4 Export (Productive) Structure Differentiation in Selected European Countries, 2012

\begin{tabular}{|l|c|c|c|}
\hline & $\begin{array}{c}\text { Industrial Sectors with RCA } \\
\mathbf{8 0 9}\end{array}$ & $\begin{array}{c}\text { Media } \\
\mathbf{n}\end{array}$ & $\begin{array}{c}\text { Concentration Index (Average Balassa } \\
\text { Index) }\end{array}$ \\
\hline Austria (AT) & 96 & 1,14 & $0,65(1,34)$ \\
Czech Republic & & 0,88 & $0,78(1,22)$ \\
(CZ) & 83 & 0,86 & $1,61(1,03)$ \\
France (FR) & 78 & 1,01 & $5,53(1,06)$ \\
Germany (DE) & 106 & 0,47 & $0,14(1,07)$ \\
Greece (EL) & 53 & 0,16 & $0,11(0,79)$ \\
Ireland (IE) & 19 & 1,12 & $0,41(1,32)$ \\
Italy (IT) & 99 & 0,84 & $0,53(1,25)$ \\
Poland (PL) & 77 & 0,69 & $0,01(2,09)$ \\
Portugal (PT) & 68 & 0,85 & $1,17(1,07)$ \\
Spain (ES) & 78 &
\end{tabular}

Source: Author's calculation on data from UNCTAD.

Figure 1 Export (Productive) Structure Differentiation in Selected European Countries, 2012

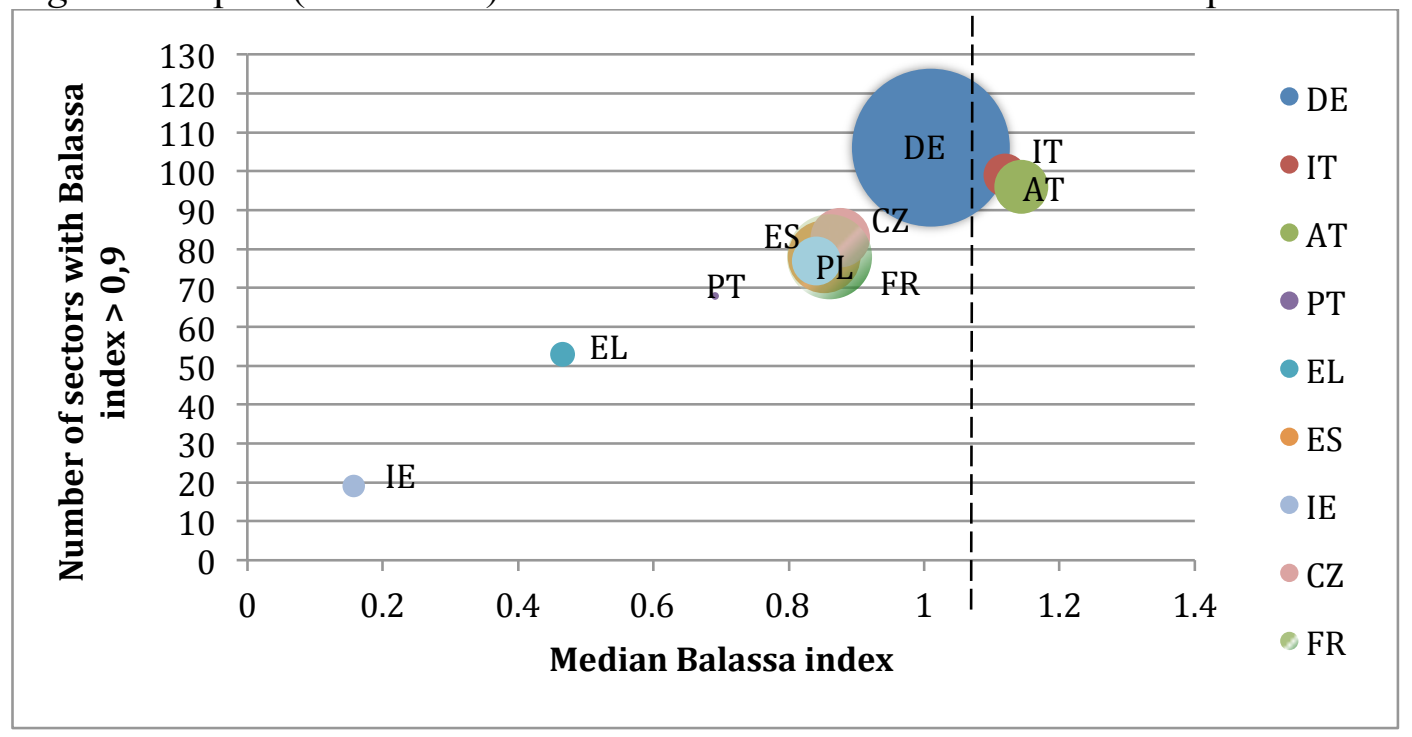

Source: Author's elaboration on data from UNCTAD.

Note: Countries abbreviations are based on Eurostat's system: Germany (DE); Italy (IT); Austria (AT); Portugal (PT); Greece (EL); Spain (ES); Ireland (IE); Czeck Republic (CZ); France (FR); Poland (PL). 
The results presented in Table 4 and Figure 1 deserve three more comments. First, the impressive GDP per-capita growth rates registered in Ireland in the second half of the 1990s and before the outbreak of the global financial crisis largely hinged on the expansion of a few dynamic sectors. The huge drop in Irish growth records and relative GDP per-capita (with respect to central economies) since 2007 now questions the sustainability of previous trends in the absence of a much wider process of structural change and productive structure diversification.

Second, large peripheral economies such as Spain and Italy appear much closer to Germany in terms of productive and export diversification than small peripheral countries do. In Italy, in particular, the majority of manufacturing sectors present Balassa indexes higher than 0,9 (99 sectors out of 166). This is likely due to the long-lasting Italian tradition in the production of some manufactured goods. This fact notwithstanding, the Italian economy seems to be stuck in a sort of structural hysteresis. In line with data contained in Table 3 , Italian manufacturing strength remain concentrated in labor and low-skill intensive sectors, while more technologically advanced sectors are largely absent from the Italian production panorama. This fact is reflected in the high level of polarization (i.e. a low concentration index) of apparent comparative advantages that characterizes the Italian economy.

Productive and export diversification have been relatively intensive in the Czech Republic and Poland. These countries are now better ranked than small peripheral eurozone countries as to the widening of their production space. Such structural changes may have favored convergence in GDP per-capita that has recently emerged between these countries and peripheral eurozone economies like Portugal and Greece (see Figure A.1). However, their longlasting effects on Poland's and the Czech Republic's growth potential are still to be verified. These effects will largely depend on the deepness of the aforementioned structural changes. Questions to be answered are the following: do structural changes in East European countries only reflect the delocalization in the home economy of low-skill labor intensive stages of more complex processes carried out by western corporations? Alternatively, do they entail some vertical integration of domestic production? A well-calibrated answer to these questions should take into account a detailed analysis of the contribution of new and export-oriented sectors to manufacturer's aggregate value added. For the time being, this topic is out of the scope of the present paper, but it certainly deserves to be considered in upcoming research efforts. 


\section{PRODUCTIVE ASYMMETRIES AND TECHNOLOGY DYNAMICS IN THE EUROZONE}

A considerable body of literature has traditionally placed great emphasis on the problems arising from economic (and monetary) integration between asymmetric economies. Balance-ofpayments-constrained models, for instance, have clearly shown that productivity backwardness in the periphery can induce peripheral countries to persistently fall behind more developed economies if the trade account equilibrium is binding (see McCombie and Thirlwall, 1994). Even admitting the possibility of running current account deficits and accumulating external debts, these imbalances must be short-lived. Very often, they have been conducive to exchange rate and/or financial crises that may ultimately have long-lasting negative effects on growth performances of an economy. The economic scenario now prevailing in the periphery of the eurozone is no exception, and there exists mounting concern about hysteretic effects of the ongoing crisis on long-run growth and employment dynamics in the periphery of the eurozone (Fitoussi and Saraceno, 2013).

In the past, the strategic answer of most less developed countries to recurrent (external) imbalances and economic downswings was the intervention of the public sector in the economic sphere so as to support domestic industrialization and eliminate structural asymmetries with respect to more developed economies. Since the beginning of the 80 s, however, the ruling policy regime has changed conformingly to the newly set neoliberal agenda. Sectoral industrial policies have been abandoned, and protectionist measures removed. Market liberalization has been implemented in order to increase competitive pressures. Industrial policy has mostly taken the form of horizontal measures. According to this view, innovation should have emerged from market-driven business initiatives rather than public sector-targeted actions. Further, sectoral allocation of productive inputs should have been driven by unfettered market mechanisms, while industrial policy should have attended to increasing the availability of productive inputs only (i.e. stimulating people to participate in the labor market by flexibilizing it; favoring capital accumulation by attracting foreign direct investment; neutrally supporting R\&D activities). Indeed, in the neoliberal perspective, long-run economic growth is a pure supply-side phenomenon. 
The current institutional design of the eurozone is totally inspired by such a philosophy. European institutions' exclusive focus on market integration, market competition, and marketdriven adjustments is nothing but the complementary part of macroeconomic rules that define price stability and balanced public budgets as the only ways to achieve rapid growth. However, protracted crisis in the periphery of the eurozone and persistent center-periphery asymmetries cast doubts on the effectiveness of such an institutional structure (Pianta and Lucchese, 2012). Pressures to rediscover and reconsider sectoral, and perhaps market-distorting, industrial policies are increasing (Aghion, Boulanger, and Cohen, 2011).

There are at least two well-grounded reasons to support such considerations. One comes from the economic theory on structural change and innovation. The other one is based on the observation of some stylized facts within the eurozone.

From a theoretical point of view, the process of structural change and production upgrading implies innovation. New sectors must emerge, and new goods be produced through a more general Smithian process of increasing division of labor (Ricottilli, 1993). New and more efficient technologies must be adopted. Innovation, in turn, requires the acquisition and development of scientific knowledge, of technological and managerial capabilities. All these perhaps intangible productive inputs share the common aspect of being partially sticky and spatially localized (Cimoli at al., 2009). Indeed, innovation and technological knowledge have a cumulative and path-dependent nature in that their evolution hinges on past innovation and knowledge (Cimoli et al., 2009; Castellacci, 2007). Further, technological competencies involved in complex productions are set in the interaction between interconnected firms and industries. In a way, the technological and productive skills of intertwined firms and sectors could be thought of as pieces of a more complex puzzle, so that they are strictly complementary to each other. Accordingly, the profitability of any single production process highly depends on the (perhaps close) availability of other connected activities, so that coordination problems may impede new production initiatives to be viable in relatively backward economies. Market failures arising from lack of coordination among interdependent productive initiatives emerge as leading sources of cumulative diverging processes between developed and (relatively) underdeveloped economies (Ros, 2000; Lorentz and Llerena, 2004). These kinds of development traps still provide strong arguments for calling public intervention in the economic sphere back so as to stimulate structural change and economic development. 
Five years after the outbreak of the global financial crisis, empirical evidence tells us that economic convergence between central and peripheral euro countries looks like a pale memory and a temporary perhaps unsustainable phenomenon. Indeed, converging trends concerned some macro-aggregated real and financial variables (see De Grauwe and Mongilli, 2005). Under the surface, however, structural and technological differences largely persisted ${ }^{17}$. These asymmetries, coupled with opposite financial positions on capital markets, capital flights away from the periphery, and diverging macroeconomic environments (interest rate hikes, credit crunch and tough austerity programs mainly concentrated in the periphery) all (inter-) acted to transform a common symmetric shock (i.e. the 2007-2008 financial meltdown) into asymmetric scenarios: a quick export-led recovery in the center versus deepening and protracted recession in the periphery. In light of these facts, the hypothesis of the endogenous nature of the eurozone as an optimal currency area is no longer credible. ${ }^{18}$

This picture gets even more dismal if we consider that some recent empirical evidence suggest center-periphery structural differences and technological gap might even widen in the foreseeable future. According to Filippetti and Archibugi (2010), “countries endowed with stronger national innovation systems [read central economies] are less affected and are better able to respond, at least in relative terms, to the present recession (Filippetti and Archibugi, 2010, page 10)". The European Commission clearly states in the 2013 Innovation Union Scoreboard that, from 2008 to 2012, "the overall process of [innovation performance] convergence witnessed in previous IUS editions has come to a halt $[\ldots]$ and has been reversed into divergence in 2012 (EU, 2013, pp. 11 - 12)”. In the case of Greece, in particular, innovation performance has dramatically weakened since 2008 on, scoring the worst negative percentage variation (-1,66\% yearly) among European countries.

\footnotetext{
${ }^{17}$ The European Commission evaluates European countries' innovation performances by computing a eightdimension index covering several aspects of the innovation process (i.e. public and private support to R\&D activities, availability of high-skilled labor, firms interaction into production networks etc...etc). Results of such analysis are published in the Innovation Union Scoreboard (IUS). According to the 2013 Innovation Union Scoreboard, peripheral countries are still classified as "moderate innovators". On the contrary, Germany is classified as one of the most innovative worldwide economic systems together with Finland, Denmark and Sweden. Most of the other central developed economies are defined as "innovator follower". Ireland is the only exception among peripheral countries, since that it belongs to the "innovation follower" group.

${ }^{18}$ Frankel and Rose (1998) first proposed the idea that monetary integration among different countries may eventually lead them to develop those properties characterizing an optimal currency area. De Grauwe and Mongilli (2005) tried to assess whether these mechanisms were at work in Europe after the introduction of the common euro currency. Their findings were cautiously on the positive.
} 
The Innovation Union Scoreboard takes into account all the 28 member states of the European Union in evaluating converging and diverging patterns inside Europe. Nonetheless, a narrower focus on central and peripheral euro countries seems to confirm the above findings. In Table 5 below we first assess changes in the degree of dispersion of euro countries' innovation performances through the well-known Theil index. We do so since that decomposition techniques applied to the Theil index allow us to measure how much of converging/diverging trends in euro countries" innovation performances might be imputed to "within-group" and/or "between-group" differences. In Table 5, we also check for the emergence of beta convergence as reflected by the degree of correlation between countries' innovation records at the beginning of a period and subsequent growth rates in innovation/technological deepening. Data on average annual growth rates are taken from Innovation Union Scoreboards 2008 and 2013, and distinguished between two different periods: pre-crisis years from 2004 to 2008, and years from 2008 to 2012.

Table 5 Converging/Diverging Trends in Innovation Performances, Central and Peripheral Eurozone Countries

\begin{tabular}{|c|c|c|c|c|c|c|c|}
\hline & 2006 & 2007 & 2008 & 2009 & 2010 & 2011 & 2012 \\
\hline \multicolumn{8}{|l|}{ Dispersion in Innovation } \\
\hline Performances (Theil index) & 0,034 & 0,033 & 0,028 & 0,030 & 0,026 & 0,029 & 0,031 \\
\hline "Within-Group" Difference & 0,012 & 0,011 & 0,007 & 0,009 & 0,007 & 0,010 & 0,009 \\
\hline (percentage of total) & $(34 \%)$ & $(33,3 \%)$ & $(25,5 \%)$ & $(28,9 \%)$ & $(26,6 \%)$ & $(34,7 \%)$ & $(30,9 \%)$ \\
\hline \multirow{3}{*}{$\begin{array}{l}\text { “Between-Group” Difference } \\
\text { (percentage of total) }\end{array}$} & 0,022 & 0,022 & 0,021 & 0,021 & 0,019 & 0,019 & 0,022 \\
\hline & $(66 \%)$ & $(66,7 \%)$ & $(74,5 \%)$ & $(71,1 \%)$ & $(73,4 \%)$ & $(65,3 \%)$ & $(69,1 \%)$ \\
\hline & \multicolumn{3}{|c|}{ 2004-2008 } & \multicolumn{4}{|c|}{ 2008-2012 } \\
\hline Beta Convergence & \multirow{3}{*}{\multicolumn{3}{|c|}{$-0,54$}} & \multirow{2}{*}{\multicolumn{4}{|c|}{0,33}} \\
\hline Beta Convergence & & & & & & & \\
\hline (excl. Greece) & & & & \multicolumn{4}{|c|}{$-0,004$} \\
\hline
\end{tabular}

Source: Author's calculations on data from Innovation Union Scoreboards 2008, 2010, 2013.

Note: Central economies are Austria, Germany, Netherlands, Finland. Peripheral economies are Greece, Ireland, Italy, Portugal, Spain. Theil index's values are computed on the base of data provided by Innovation Union Scoreboards 2010 and 2013. Beta convergence calculations for the 2004-2008 time span rely on data provided by 2008 Innovation Union Scoreboard. Data contained in the 2013 Innovation Union Scoreboard are used for assessing beta convergence since 2008 . 
According to Table 5, mild signs of decreasing heterogeneity between central and peripheral euro countries were registered between 2006 and 2008. Most of this trend, however, was due to higher "within-group" homogeneity, rather than lower technological differences between central and peripheral countries. Indeed, "between-group" differences remain sustained and broadly unchanged all along the time span covered by our analysis. They still account, on average, for more than two-thirds of the observed dispersion.

Data contained in the 2008 Innovation Union Scoreboard seem to show some sort of beta convergence between central and peripheral countries. This data, however, should be viewed with caution since subsequent revisions of European countries' innovation performances generally updated upward evidence about the central-periphery technological gap. Furthermore, the above tendency seems to be reversed since 2008 on, so that a deepening innovative gap now divides peripheral from central economies. This last result is highly influenced by the worrisome negative innovative performance characterizing Greece during the last five years. Nonetheless, even dropping Greece from our sample, center-periphery technological convergence has stopped and substantially vanished since the outbreak of the present crisis. This picture could get even worse if we consider that several pieces of information contained in the multi-dimensional innovation performance index are updated until 2010. It is very likely that they do not reflect in a full extent the perverse effects of a protracted recession on the innovation parabola of peripheral economies.

A closer look at the single components of the aggregated innovation performance index computed by the European Commission reveals that center-peripheral gaps are particularly relevant in three fields. First, peripheral economies (with the exception of Ireland) lag far behind central economies as to the accumulation of human resources as measured by the percentage of new doctorate graduates per thousand inhabitants (aged 24-64), and by the percentage of people completing upper secondary and tertiary education levels. Second, private and public financing of research activities and innovation, and firms involvement in R\&D expenditures are particularly disappointing in peripheral countries with respect to data registered in central economies. Finally, peripheral countries seem to be persistently afflicted by a low capability to create shared innovations through (productive) linkages inside their own national innovation systems. 
Such empirical evidence is not surprising. According to the cumulative nature of innovation processes outlined above, productive structure asymmetries are naturally reflected in cross-country different intensities with which private agents undertake innovative activities (Bilbao-Osorio and Rodriguez-Pose, 2004; Filippetti and Archibugi, 2010). In light of this, public authorities in the periphery should try to (more than) compensate private sector backwardness and overcome technology lock-in phenomena by devoting special attention to innovation (both directly and indirectly by properly incentivizing private sector-led innovation). However, data on R\&D expenditures (as a percentage of GDP) by the government and high education sector seem to describe a different reality (see Figure 2).

Figure 2 Government Plus High Education Sector and Private Expenditures on R\&D Activities in Percentage of GDP, Selected Countries, 2011

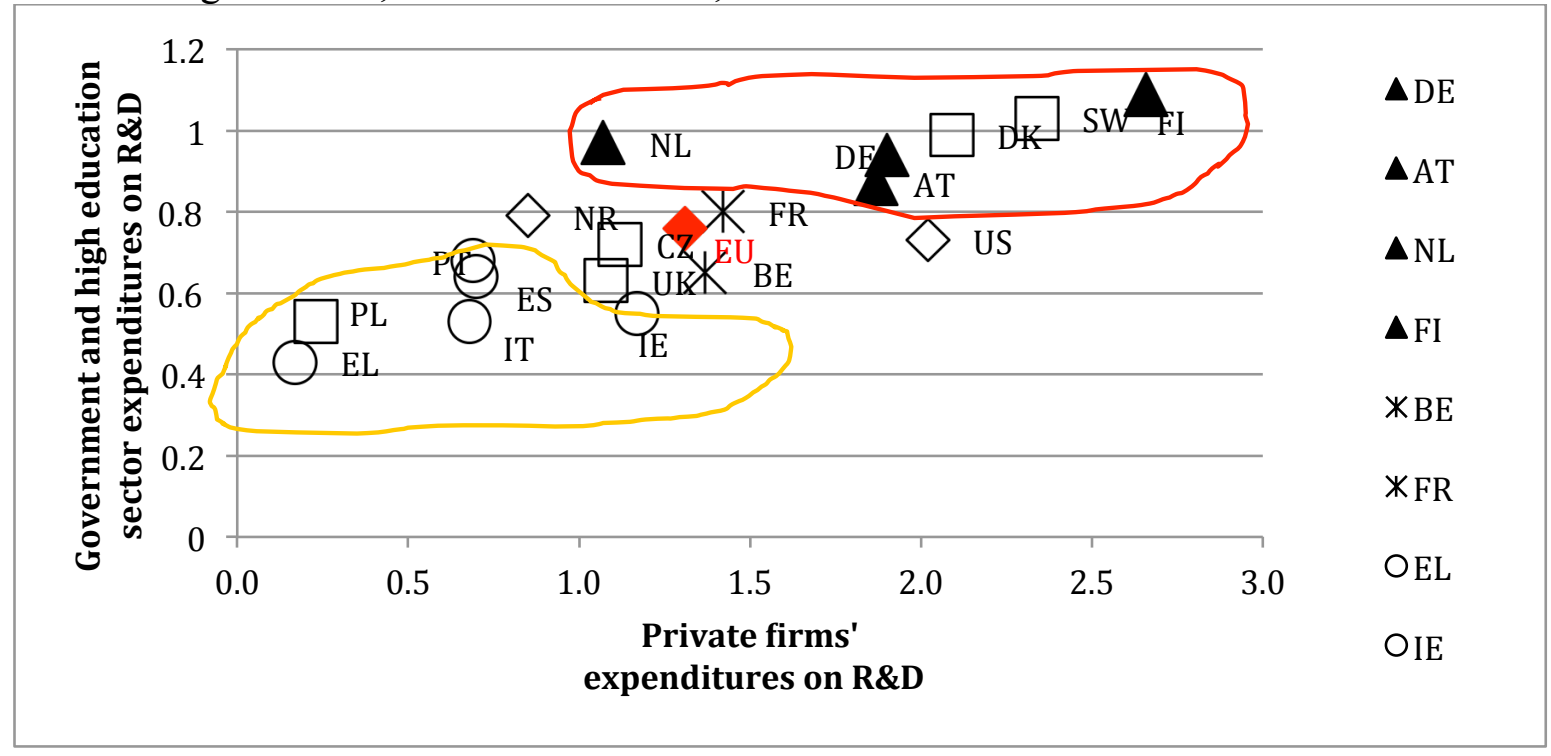

Source: Author's calculations on data from Eurostat.

Note: Data on Greece (EL) refer to 2007. Data on United States (US) refer to 2009. Country sample in Figure 2 also includes Belgium (BE), Denmark (DK), Nederland (NL), Norway (NR), Sweden (SW), United Kingdom (UK), and United States (US).

Indeed, peripheral countries are clustered in the south-west part of Figure 2 with respect to the north-east position of central economies. In the periphery, a low propensity to invest in innovative activities by the private sector is exacerbated by insufficient efforts by national governments and high education systems. 


\section{WHAT'S NEW FOR EUROPEAN INDUSTRIAL POLICY?}

Structural and technological convergences are not automatic outcomes of economic and monetary integration. On the contrary, according to Cimoli at al. (2009), specific institutional settings and public policies are required to deal with structural asymmetries between countries. The central-peripheral technological divide in the eurozone does not seem to be an exception.

So far, European industrial policy has largely amounted to a considerable body of rules aiming to eliminate market barriers, limit national governments' actions that may distort market mechanisms, and enforce a business-driven approach to innovation. These measures are likely inappropriate and insufficient to confront with persisting (or widening) center-periphery technological and economic gaps in the eurozone. This is even more so if we think that current "economic union consists of the internal market and a very modest set of cohesion [read regional] policies (Pelkmans, 2006, p.5)". Given the above evidence, two general principles should guide the reform of European industrial policy and the implementation of a new industrial strategy in the upcoming years.

First, future European industrial policy should have a strong regional character. With this term, we mean that peripheral countries' productive development should become the main goal of industrial measures undertaken by European institutions, and that industrial policy should emerge as the strongest action to favor regional cohesion and center-periphery convergence. Cohesion funds, structural funds, and financial resources devoted to R\&D and innovation should become parts of a unique integrated policy focused on peripheral countries' productive development. Indeed, more balanced productive and trade links would likely rise inside the eurozone should center and peripheral countries present more technologically homogeneous productive structures, and compete on more equitable bases. A strong emphasis on regional productive development may likely become the main way for "europeanizing" the European productive system and removing the existing center-periphery dichotomy.

Second, market coordination failures due to productive assets complementarities (see complementarities between a high-skilled labor force, and R\&D and physical investment, for instance) shape structural changes in the center and in the periphery of the eurozone. As a consequence, European industrial policy should consider demand-side factors alongside supplyside ones as relevant forces determining productive structures' evolution and productivity dynamics inside Europe. Productive structures in the periphery may credibly upgrade only if 
efforts to improve labor force skills would be coupled with rising regional demand for high-skill workers due to increasing productive investment and newly established high-tech productions.

What are the concrete implications of the above principles for the EU budget for industrial policy, as well as for the sectors expected to be most relevantly affected by EU intervention; and what are the specific measures to adopt? Let us discuss some points.

The sovereign debt crisis and the ensuing constraints (self-imposed by EU institutions or set by financial markets) to member States' budgets largely prevent national governments from implementing vigorous industrial measures. Thus, European institutions should take a much more interventionist stance, and considerably expand financial resources devoted to an integrated cohesion-industrial-technology policy. Obviously, this would entail providing EU institutions with more conspicuous financial resources than there are now. Eurobond issuances in a future European or at least in a eurozone federal entity might be the financial vehicle needed to pursue this task. Unfortunately, following Fiorentini and Montani (2013), the European Council seems to have recently preferred taking a different way, downsizing the EU budget instead of expanding it ${ }^{19}$.

The 2013 European Innovation Scoreboard clearly stresses peripheral eurozone countries' deep lags with respect to both central economies and international foreign competitors with respect to the accumulation of human resources, identified here as higher education level and professional skills attained by the domestic labor force. This fact notwithstanding, from 2008 to 2012, the ongoing crisis has forced most peripheral economies to cut high education funding. Cuts amount to far more than 10 percent of pre-crisis resources in Greece, Italy, Portugal, Spain and Ireland. By contrast, public support of higher education has increased in Germany and Austria (European University Association, 2012). EU industrial/cohesion funds provided to peripheral countries might primarily aim to fill such a widening discrepancy. Two actions are suggested. First, EU funds to the periphery should support domestic expenditures on high education systems so as to perhaps indirectly favor a larger domestic availability of high-skilled workers. EU financing of fellowship programs, and of modern and technologically advanced education infrastructures are examples of possible

\footnotetext{
${ }^{19}$ On $8^{\text {th }}$ February 2013, the European Council has decided to cut EU budget to 1\% of EU GDP. Further, a eight percentage points cut in cohesion and regional funds has been prospected in the framework of the 2014-2020 multiperiod financial planning. Ultimately, Horizon 2020, i.e. the European Commission 2014-2020 R\&D program, establishes that European funds for R\&D and innovation activities will amount to 80 billion from 2014 to 2020, i.e. 0,08 percent of $2012 \mathrm{EU}$ GDP yearly. It is very hard to see how these modest (to be fair) measures could effectively address inside-Europe discrepancies noted in the paper.
} 
measures in this vein. Second, and in line with the previous point, EU emphasis on higher education systems should also encourage research activities to be carried out by universities and governmental-public centers in peripheral economies. In this sense, EU support should aim at strengthening physical infrastructures (say labs) devoted to host research activities; enlarging the domestic research community; and financing international research programs held in peripheral countries. Positive spill-overs of these kinds of initiatives on the economic performances of peripheral countries may be expected to be considerable, though not immediate. Indeed, according to Filippetti and Archibugi (2010), the more skilled and wellprepared a country's labor force is, the more resilient it is to economic downswings. Further, according to Dosi et al. (2006), increasing efforts on basic research by higher education and governmental institutes are functional in creating more business-friendly environments.

Institutions involved in the national innovation system are often not well integrated in peripheral countries. A further goal of EU industrial policy may thus focus on tightening and widening innovation linkages inside local productive systems. We think about the creation of EU-funded research centers in the periphery that should involve higher education institutions and private enterprises in joint innovation processes. On the one hand, these centers should focus on applied innovations, perhaps based on new basic scientific knowledge. In this sense, it would be fundamental to develop their links with the university system, and support researchers' mobility among research centers (from basic research to applied one, for instance) in order to facilitate knowledge dissemination. On the other hand, research centers' linkages with the private business sector would be intended to ease commercially valuable applications of technological innovations. Indeed, EU-funded research centers may purse three distinct but connected tasks. First, they may act as catalysts of production investment aiming to exploit joint public-private innovations. Second, they may act as autonomous embedded public institutions recollecting and sharing information on firms' needs and innovation opportunities that are so important to properly implement industrial and innovation policies (Rodrik, 2008). Third, they may track the effectiveness of R\&D efforts in terms of innovations applicable to commercial uses.

Coordination failures very often prevent radical structural changes to take place in relatively poor productive structures. In this sense, the above initiatives may well turn out to be useless insofar as a better trained labor force, more qualified workers, and a higher stock of scientific knowledge do not find adequate employment opportunities in the domestic productive 
system. With such employment opportunities lacking, periphery-to-center brain drain would likely emerge or intensify, eventually reinforcing center-periphery technological asymmetries (Brussels Think Tank Dialogue, 2013).

According to the intrinsic properties of technological knowledge, innovative firms would not naturally localize in backward economies. EU future industrial policy should take this into account, and question if unfettered market competition between asymmetric productive structures constitutes a sort of unfair competition between differently equipped competitors. Paradoxically, competitive pressures may intensify in the long run once public institutions temporaryily defend initial losers.

In terms of our analysis, the above consideration might suggest that a European industrial development authority should be created to interact with economic agents and coordinate investment initiatives in order to foster innovation in the European Union as a whole, and in peripheral countries in particular. Historical experience of the Japanese Ministry for Trade and Industry (MITI) might somehow inspire the design of European institutions capable of implementing EU industrial policy. EU industrial policy should then envisage some perhaps market-distorting measures incentivizing innovative firms' localization in peripheral countries. Public support to innovative activities may take the form of easy credit or public financing of productive investments, as well as tax incentives and subsidies linked to R\&D efforts.

As to the financing of innovative entrepreneurial initiatives, regionally-oriented easy credit policy might likely be fundamental to restore growth in the periphery should the ongoing credit crunch persist and credit accessibility remain extremely difficult in those economies. Specifically, such kinds of intervention may be implemented through the action of the European Investment Bank (EIB). From the very onset, EIB has been conceived as a public development bank providing funds mainly for infrastructural projects (Griffith-Jones and Tyson, 2013). More recently, it has started to focus on the development of technologically advanced small and medium size firms, as well. In the near future, EIB's commitment to industrial development goals should be reinforced. Indeed, EIB's concern about infrastructure financing, although appreciable, cannot fully remove economic bottlenecks and coordination failures that prevent productive upgrading to take place in the periphery of the eurozone. EIB's financial support to productive development should thus become a main pillar of EIB's action. EIB's intervention should first go far beyond the provision of public guarantees to private agents' financing of innovation efforts. It may be asked to adopt a perhaps riskier direct financial stance. Second, 
EIB's credit policy should be anti-cyclical in nature. Actually, the co-financing philosophy that informs the EIB's operation intrinsically has a pro-cyclical character whenever austerity programs cut national funds for public investment and depress private agents' propensity to take on risk (let's say animal spirits). EIB's financial load of supported projects should thus increase in time of financial and economic distress. Last but not least, EIB should start to consider program financing as a policy tool for supporting coordinated innovation initiatives. Such a farsighted, wide financial perspective may likely improve EU institutions' capability to effectively address coordination failures in backward productive systems.

As to the adoption of tax and subsidy incentives, such measures should be graduated according to the degree of embeddedness of new production activities in the local productive system. For instance, public subsidies or tax exemptions granted to productive investment might augment in case of shared innovation activities among multiple actors that increase the density of peripheral national innovation systems. Further, such regionally-based incentives should be temporary and submitted based on conditionality requirements. According to a well-known carrot-and-stick argument, public support must be gained and (temporarily) maintained provided that supported firms perform well in terms of easily verified targets such as export shares on foreign markets and/or patented innovations.

Some final notes concern EU industrial policy if considered from a wider perspective than the previous focus on its usefulness as a regional development policy tool. First, even though sectoral industrial policies have been largely disregarded by EU institutions in the last decades, they are now implicitly admitted back in the Horizon 2020 program, insofar as the EU Commission identifies some specific fields of research and productive efforts should concentrate in. This is the case of all sectors producing environmentally friendly technologies. Indeed, rising worldwide concern about environment protection seems to suggest that sectors generating such kind of innovations might expand rapidly in the near future. Accordingly, industrial policy spurring development in those fields may turn out to be divisive in leading Europe in acquiring competitive advantages in the production of, let's say, energy-saving goods. In line with the above observations, such policies should address both the supply-side and the demand-side of the market. As to the supply side, production incentives may stimulate the emergence of highly competitive European production networks in targeted sectors. On the demand side, incentives for the adoption of eco-friendly technologies could create a domestic market large enough that domestic producers can profitably supply. Past empirical experience, 
for instance, shows that stricter environmental regulation, by expanding domestic demand for renewable energy and energy-saving goods and processes, may eventually lead to improving export performances in those same industries (Costantini and Crespi, 2008).

Second, in contrast to what is supposed by most supply-side growth models, demandside and supply-side factors feedback each other to determine productivity dynamics and countries' external competitiveness. Demand stimuli in the form of EU-level public procurement of European-made new technologies and investment goods may thus contribute to set in virtuous circles between enhanced European competitiveness and expanding European firms' market shares on new dynamic productive sectors. Remarkable increases in EU-level public investment demand may be desirable to both favor recovery out of the present crisis and trace European long-run development path. 


\section{FINAL KEYNESIAN REMARKS}

Peripheral euro countries urgently need investment. Increased demand injections in the form of higher investment expenditures could first act as counter-cyclical forces contrasting the ongoing crisis. More importantly, productive investment could help reduce structural and technological gaps that still divide peripheral from central economies. Actually, should the above structural asymmetries persist, external balance constraints would likely impose protracted stagnation on peripheral countries. Growth spurts would probably be unsustainable and conducive to wellknown macroeconomic imbalances and financial havoc.

Peripheral countries' investment needs call for EU intervention insofar as budget restrictions make national governments anti-cyclical policies inactive. EU intervention should take the form of regionally-focused industrial policy. Such kind of measures should take inspiration from Keynes's lesson on the intrinsic instability of market economies. First, an EU plan for productive investment in the periphery of the eurozone should try to apply Keynes's ideas of a "somehow comprehensive socialization of investment...[as] the only means of securing an approximation to full employment (Keynes, 1972a, pag. 378)". Second, EU industrial measures may try to accomplish with Keynes's perspective on what public intervention aim should be. Indeed, Keynes clearly states in the "End of the Laissez-Faire":

The most important agenda of the State relates not to those activities which private individuals are already fulfilling, but to those functions which fall outside the sphere of the individual, to those decisions which are made by no one if the State does not make them. The important thing for government is not to do things which individuals are doing already, and to do them a little better or a little worse; but to do those things which at present are not done at all (Keynes, 1972b, page. 291)

Further:

I believe that some coordinated [italics is of the authors] act of intelligent judgment is required as to the scale on which it is desirable that the community as a whole should save, the scale on which these savings should go abroad in the form of foreign investments, and whether the present organization of the investment market distributes savings along the most nationally productive channels. I do not think that these matters should be left entirely to the chances of private judgment and private profits, as they are at present (Keynes, 1972b, pag. 292) 
Market failures are pervasive in the field of basic research and on financial markets, more so in times of economic contraction and widespread uncertainty. Lack of coordination among possibly intertwined innovation initiatives severely discourages technological improvements and production upgrading in peripheral countries. These constitute structural problems that currently dampen development in the periphery of the eurozone, and put eurozone survival at risk. EU industrial policy should boldly address them in the near future. 


\section{REFERENCES}

Aghion P., Boulanger J., Cohen, E. (2011) - Rethinking Industrial Policy, Bruegel Policy Brief 2001/04.

Akamatsu K. (1962) - Historical pattern of economic growth in developing countries, The Developing Economies, vol. 1 (1), pp. 3 - 25.

Bachus D.K., Kehoe P.J., Kehoe T.J. (1992) - In Search of Scale Effects in Trade and Growth, Journal of Economic Theory, vol. 58 (2), pp. 377 - 409.

Best M. (2013) - Productive Structures and Industrial Policies in the EU, paper presented at the $19^{\text {th }}$ Euromemo Group annual workshop, freely downloadable from website: euromemo.eu.

Bilbao-Osorio B., Rodriguez-Pose, A. (2004) - From R\&D to Innovation and Economic Growth in the EU, Growth and Change, vol. 35 (4), pp. $434-455$.

Bibow J. (2012) - The Euro Debt Crisis and Germany's Euro Trilemma, Levy Economics Institute Working Paper n.721.

Botta A. (2013a) - Fiscal Policy, Eurobonds and Economic Recovery: Some Heterodox Policy Recipes against Financial Instability and Sovereign Debt Crisis, Journal of postKeynesian Economics, vol. 35 (3), pp. 417 - 442.

Botta A. (2013b) - Conflicting Claims in the Eurozone? Austerity's Myopia and the Need for a European Federal Union in a post-Keynesian Center-Periphery Model", forthcoming on Review of Keynesian Economics.

Brussels Think Tank Dialogue (2013) - The EU's Next Industrial Policy: Panacea Against the Rampant Job Crisis?, Summary of the conference on "Federalism or Fragmentation? Spelling out Europe's F-word". Report downloadable from the website www.egmontinstitute.be.

Castellacci F. (2007) - Evolutionary and New Growth Theory. Are They Converging?, Journal of Economic Surveys, vol. 21 (3), pp. 585 - 627.

Cimoli M., Dosi G., Nelson R., Stiglitz J. (2009) - Institutions and Policies Shaping Industrial Development: An Introductory Note, in Cimoli, M., Dosi, G., Stiglitz, J. (eds) - Industrial Policy and Development: The Political Economy of Capabilities Accumulation, Oxford: Oxford University Press.

Costantini V., Crespi F. (2008) - Environmental Regulation and the Export Dynamics of Energy Technologies, Ecological Economics, vol.66 (2 - 3), pp. 447 - 460.

De Grauwe P. (2010) - The Financial Crisis and the Future of the Eurozone, Bruges European Economic Policy Briefings n.21. 
De Grauwe P., Mongilli F. P. (2005) - Endogeneities of Optimal Currency Areas. What Brings Countries Sharing a Single Currency Closer Together?, European Central Bank Working Paper n.468.

Dosi G., Llerena P., Sylos Labini M. (2006) - The Relationship between science, technologies and their industrial exploitation: An illustration through the myths and realities of the so-called "European Paradox", Research Policy, vol. 35, pp. 1450 1464.

Dullien S., Fritsche U. (2009) - How Bad is Divergence in the Eurozone? Lessons from the United States of America and Germany, Journal of Post-Keynesian Economics, vol. 31(3), pp. $431-457$.

European Commission (2013) - Innovation Union Scoreboard, Bruxelles.

European University Association (2012) - European University Association Public Funding Observatory 2012. Report downloadable from EUA website: www.eua.be.

Filippetti A., Archibugi D. (2010) - Innovation in times of crisis: National Systems of Innovation, Structure, and Demand, Research Policy, vol. 20 (2), pp. 179 - 192.

Fiorentini R., Montani G. (2013) - Beyond Austerity. A European Recovery Policy is Feasible, Economics Department WP Series n.6, University of Verona.

Fitoussi J.P., Saraceno F. (2013) - European Economic Governance: The Berlin-Washington Consesus, Cambridge Journal of Economics, vol. 37(3), pp. 479 - 496.

Frankel J., Rose A. (1998) - The Endogeneity of the Optimal Currency Area Criteria, Economic Journal, vol. 108 (449), pp. 1009 - 1025.

Gibson B., Van Seventer D. (2000), A Tale of two Models: Comparing Structuralist and Neoclassical General Equilibrium Models for South Africa, International Review of Applied Economics, vol. 14(2), pp. 149 - 170.

Griffith-Jones S., Tyson J. (2013) - The European Investment Bank. Lessons for Developing Countries, WIDER Working Paper n. 2013/019.

Hein E., Trueger A., van Treeck T. (2011) - The European Financial and Economic Crisis: Alternative Solutions from a (Post-) Keynesian Perspective, IMK Working Paper 9/2011.

Herzer D., Nowak-Lehmann D. (2006) - What Does Export Diversification Do for Growth? An Econometric Analysis, Applied Economics, Applied Economics, Vol.38 (15), pp. $1825-1838$.

Keynes, J.M. (1972a) - The General Theory of Employment, Interest and Money, in: The Collected Writings of John Maynard Keynes, vol. 7 (The General Theory), Macmillan Publishing. 
Keynes, J.M. (1972b) - The end of the Laissez-Faire, in: The Collected Writings of John Maynard Keynes, vol. 9 (Essays in Persuasion), Macmillan Publishing.

Klinger B., Lederman D. (2004) - Discovery and Development: An Empirical Exploration of "New Products", World Bank Policy Research Working Paper n.3450.

Kojima K. (2000) - The "flying geese" model of Asian Economic development: Origin, theoretical extensions, and regional policy implications, Journal of Asian Economics, vol. 11 (4), pp. $375-401$.

Krugman P. (1981) - Trade, Accumulation and Uneven Development, Journal of Development Economics, vol. 8 (2), pp. 149 - 161.

Krugman P. (2009) - The Return of Depression Economics and the Crisis of 2008, New York: W.W. Norton and Company.

Imbs J., Wacziarg R. (2003) - Stages of Diversification, American Economic Review, vol. 93 (1), pp. $63-86$.

Lane P.R. (1996) - Trade Specialization, Endogenous Innovation and Growth, Journal of Economic Integration, vol. 11 (4), pp. 492 - 509.

Lee J. (1995) - Capital Goods Imports and Long-run Growth, Journal of Development Economics, vol. 48 (1), pp. $91-110$.

Lorentz A., Llerena P. (2004) - Cumulative Causation and Evolutionary Micro-founded Technological Change. On the Determinants of Growth Rates Differences, Revenue économique, vol. 55 (6), pp. $1191-1214$.

Matsuyama K. (1992) - Agricultural Productivity, Comparative Advantage, and Economic Growth, Journal of Economic Theory, vol. 58 (2), pp. 317 - 334.

McCombie J.S.L, Thirlwall A.P. (1994) - Economic Growth and Balance of Payments Constraint, London: Macmillan.

Pelkmans J. (2006) - European Industrial Policy, Bruges European Economic Policy Briefings n. 15.

Perez-Caldentey E., Vernengo M. (2012) - The Euro imbalances and Financial Deregulation: A Post Keynesian Interpretation of the European Debt Crisis, Levy Economics Institute Working Paper n.702.

Pianta M., Lucchese M. (2012) - Industrial and Innovation policies in the European Union, in Garibaldo F., Baglioni M., Casey C., Telljonhann,V. (eds) - Workers, Citiziens, Governance: Socio-Cultural Innovation at work, Peter Lang International Academic Publishers. 
Ricottilli M. (1993) - Technical Progress and Structural Change in the Process of Economic Development, Proceedings of the $5^{\text {th }}$ European Association Evolutionary Political Economy (EAEPE) Conference, Barcelona.

Rivera-Batiz L., Romer P. (1991) - Economic Integration and Economic Growth, Quarterly Journal of Economics, vol. 106 (2), pp. 531 - 557.

Rodrik D. (2007) - Industrial Development: Some stylized facts and Policy directions, in UNDESA Report "Industrial Development for the $21^{\text {st }}$ Century. Sustainable Development Perspectives", New York.

Rodrik D. (2008) - Normalizing Industrial Policy, Growth and Development Commission WP n.3.

Ros J. (2000) - Development Theory and the Economics of Growth, Ann Arbor (USA): The University of Michigan Press.

Simonazzi A., Ginzburg A., Nocella G. (2013) - Economic Relations Between Germany and Southern Europe, Cambridge Journal of Economics, vol. 37 (3), pp. 653 - 675.

Stockhammer E. (2012) - Euro-Keynesianism? The Financial Crisis in Europe, Radical Philosophy, n.175, pp. $2-10$.

Taylor L. (1991) - Income Distribution, Inflation, and Growth: Lectures on Structuralist Macroeconomic Theory, Cambridge (USA): MIT Press. 


\section{APPENDIX A. MACROECONOMIC CONVERGENCE-DIVERGENCE TRENDS AMONG SELECTED EUROPEAN COUNTRIES}

Figures A.1, A.2 and A.3 below provide evidence about comparative macroeconomic trends, as well as likely connected external imbalances, among eurozone countries in the last two decades.

Figure A.1 portrays eurozone center-periphery real GDP per-capita convergencedivergence patterns from 1991 to 2012 . According to the analysis carried out in the main text, in Figure A.1 we take into account the dynamics of real GDP per-capita in Czech Republic and Poland also. Germany's real GDP per-capita is taken as benchmark. From 1995 until the outbreak of the most recent worldwide financial crisis (grey zone in Figure A.1), increasing economic and financial integration between European countries, here witnessed by converging (and, since 2001, broadly equal) 10-year government bonds' yields (see Figure A.2), fed peripheral countries' catching-up on Germany. Irish macro-aggregated performance and takeover on central European countries is astonishing. Convergence is far more modest but still significant in the case of Spain (since 1995) and Greece (since 2000), as well as in the case of the abovementioned East European countries.

The effects of the ongoing crisis appear clearly since 2007 on. The disappointing Irish performance with respect to Germany is impressive. Perhaps even more worrisome, newly established divergence increasingly divides relatively poor peripheral countries (Greece, Portugal, Spain and Italy) from Germany and the other central economies. At the end of 2012, Greek GDP per-capital is less than 50 percent of the German one (i.e. it is now lower than it was in 2001 at the beginning of the common currency experiment). Finally, Czech Republic and, in particular, Poland seem to have been less vulnerable to the worldwide financial crisis and to the ensuing sovereign debt crisis than peripheral eurozone countries do.

According to the arguments presented in the main text, initial finance-led centerperiphery convergence, when associated to persistent center-periphery asymmetries, has been reflected in widening external imbalances (see Figure A.3). Relevant current account deficits started to emerge in the Balance of Payments of most peripheral countries (Ireland is the exception) in the second half of the 90s (light grey in Figure A.3). They further increased in the years immediately before the 2007-2008 financial meltdown (dark grey in Figure A.3). The worldwide financial crisis has eventually brought to an end irrational euphoria on financial markets. Since 2008, painful macroeconomic adjustments have been improving peripheral countries' external imbalances at the cost of collapsing domestic markets. 
Figure A.1 Converge-Divergence Pattern in Real GDP Per-Capita Among Selected European Countries (Germany $=100)$

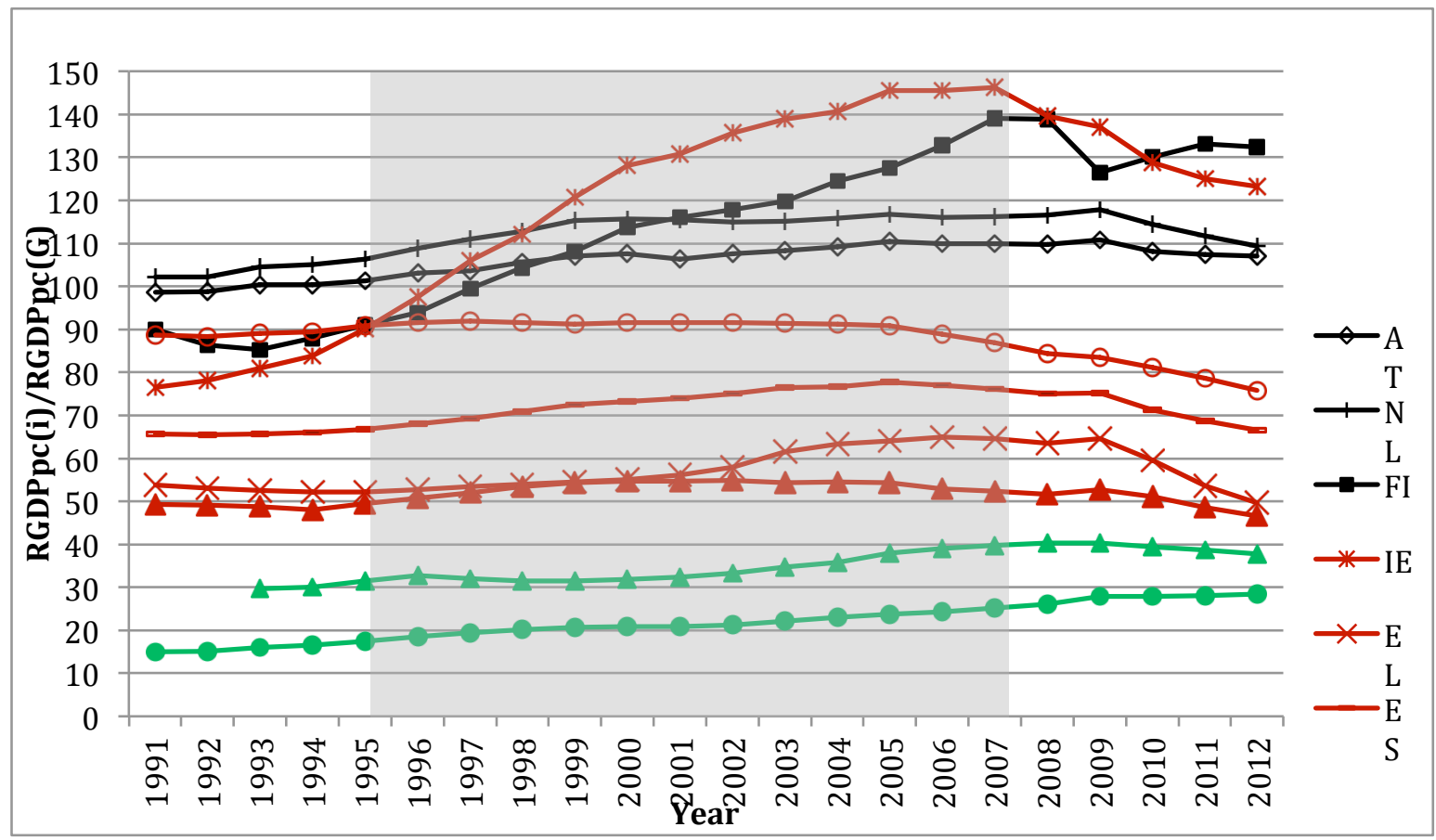

Source: Author's elaboration of data from UNCTAD.

Figure A.2 Financial Integration Among Eurozone Countries and Interest Rate Dynamics

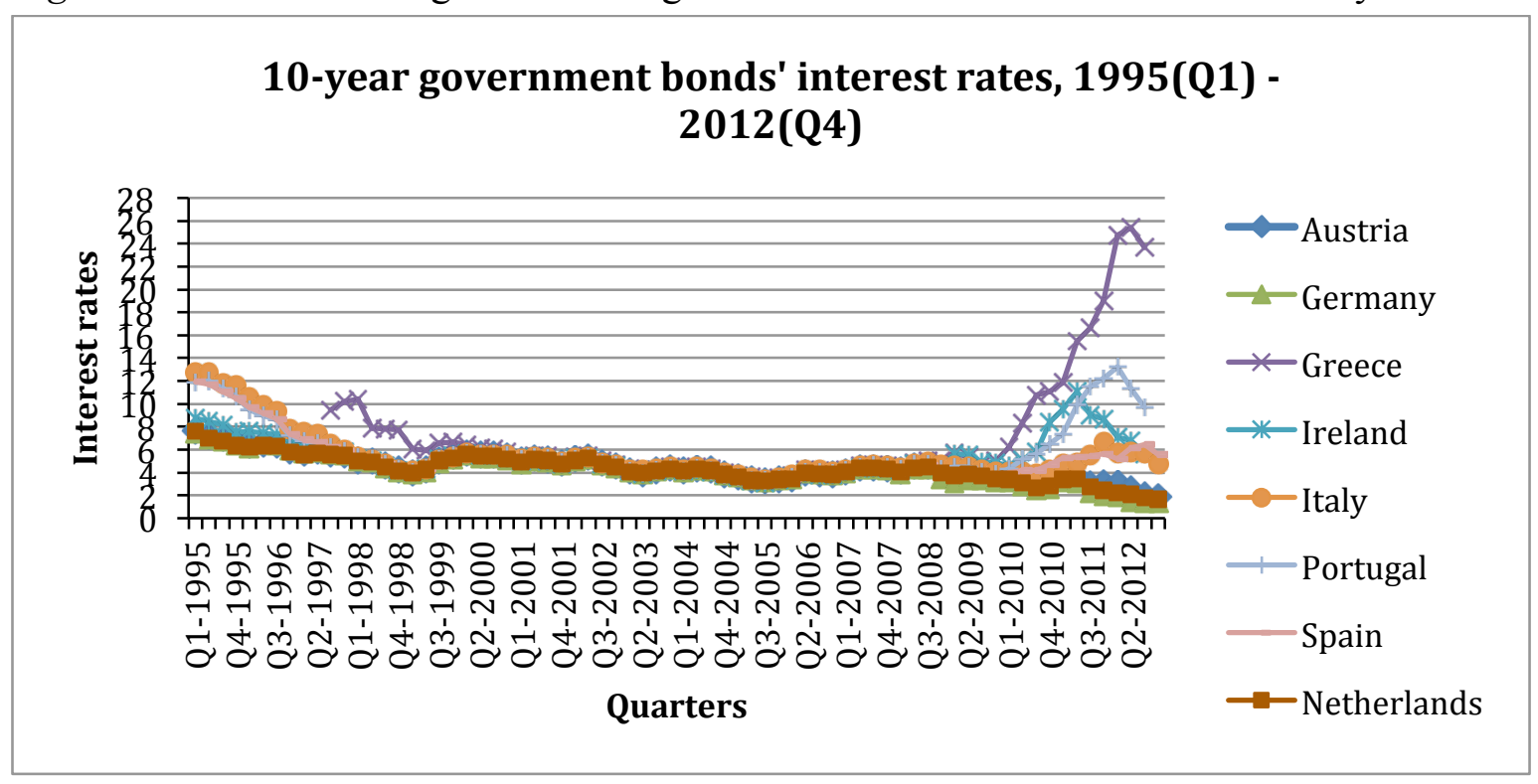

Source: Author's representation of data from OECD. 
Figure A.3 Current Account Deficits/Surplus (Percentage of GDP) in Peripheral Euro Countries and in Germany



Source: Author's representation of data from UNCTAD. 